\title{
Identifikasi Dampak Penggunaan Sistem Informasi Rumah Sakit (SIRS) Terhadap Pelayanan Kesehatan Menggunakan Hot-Fit Model 2006
}

\author{
Frendy Rocky Rumambi ${ }^{1}$, Salahudin Robo ${ }^{2}$, Citra Amalia, \\ ${ }^{1}$ Fakultas Informatika, Informatika, Universitas Prisma Manado, Manado, Indonesia \\ ${ }^{2}$ Fakultas Teknik dan Sistem Informasi, Sistem Informasi, Universitas Yapis Papua, Jayapura, Indonesia \\ ${ }^{2}$ Fakultas Ilmu Komputer, Teknik Informatika, Universitas Muhammadiyah Palangkaraya, Palangkaraya, Indonesia \\ Email: ${ }^{1}$ frensrumambi@gmail.com, ${ }^{2}$ salahudinrobo759@gmail.com, ${ }^{3, *}$ citracicit@gmail.com \\ *) Email Penulis Korespondensi: citracicit@gmail.com
}

\begin{abstract}
Abstrak-Sistem Informasi Rumah Sakit (SIRS) adalah sebuah sistem informasi terintegrasi yang bentujuan untuk menangani semua proses manajemen rumah sakit, mulai dari layanan diagnostik, tindakan medis, rekam medis, farmasi, gudang farmasi, penagihan, database personalia, penggajian, akuntansi hingga pada manajemen kontrol. Konstitusi Indonesia No. 44 pasal 52 ayat 1 Tahun 2009, meyebutkan bahwa setiap "Rumah sakit di seluruh Indonesia diharuskan mencatat dan melaporkan semua kegiatan yang terjadi di dalam sebuah rumah sakit". PERMENKES No. 1171 Tahun 2011, Pasal 1 ayat 1, menyebutkan "Masing-masing Rumah Sakit wajib menerapkan SIRS. Oleh karena itu RSUD Dr. Samratulangi Tondano Kabupaten Minahasa Sulawesi Utara menggunakan SIRS untuk meningkatkan kinerja karyawan dalam memberikan pelayanan kesehatan kepada masyarakat. Masalah yang dibahas adalah mengidentifikasi dampak penggunaan System Informasi Rumah Sakit (SIRS) terhadap pelayanan kesehatan. Tujuan dari penelitian ini adalah untuk melihat dampak penggunaan sistem dari SIRS berdasarkan empat indikator yang terdapat dalam metode Teknologi Organisasi Manusia 2006 (HOT-Fit) selain metode DeLone dan McLean Success 2003. Peneliti mengambil sebanyak 150 responden pengguna SIRS secara acak, data dikumpulkan dan dianalisis menggunakan perangkat lunak SPSS dan AMOS. Keempat hipotesis yang berasal dari tiga komponen yaitu "Teknologi", "Manusia" dan "Organisasi" memiliki dampak positif dan memberikan manfaat bersih terhadap penggunaan system. Singkatnya, sebagian besar pengguna SIRS hanya fokus pada fungsi untuk registrasi dan administrasi daripada fungsi klinis. Ketersedian unit IT dan personel TI memengaruhi penggunaan SIRS.
\end{abstract}

Kata Kunci: Sistem Informasi Rumah Sakit, DeLone And McLean Success 2003, Human Organization Technology (HOT) Fit 2006

\begin{abstract}
Hospital Information System (SIRS) is an integrated information system that aims to handle all hospital management processes, ranging from diagnostic services, medical data measures, medical records, pharmaceuticals, pharmaceutical warehouses, billing, personnel databases, payroll, and accounting to the control management. Based on Indonesian Constitution No. 44 Article 52 year 2009, paragraph 1 states that "Indonesian hospitals are required to record and report all activities that occur within a hospital". On the Indonesia ministry regulation, PERMENKES No. 1171 year of 2011, Article 1 paragraph 1 states that "Each hospital is required to apply SIRS". Therefore Dr. Samratulangi Tondano District Hospital of Minahasa Regency in the North Sulawesi uses SIRS to improve employee performance in providing health services to the community. The paper discussed how to identify the impact of the use of Hospital Information Systems (SIRS) on health services. The purpose of this study is to look at the impact of the use of the SIRS system based on four indicators contained in the 2006 Human Organizational Technology (HOT-Fit) method in addition to the DeLone and McLean Success 2003 methods. By taking 150 respondents of SIRS users randomly, data were collected and analyzed using SPSS and AMOS software.The four hypotheses derived from three components namely "Technology", "Human" and "Organization" have a positive impact and provide a net benefit to the use of the system. In short, the majority of users SIRS only focuses on functions for registration and administration rather than clinical functions. The availability of IT units and IT personnel influences the use of SIRS as well.
\end{abstract}

Keywords: Hospital Information System, DeLone And McLean Success 2003, Human Organization Technology (HOT) Fit 2006

\section{PENDAHULUAN}

Sistem Informasi Rumah Sakit (SIRS) telah banyak di terapkan dalam bidang kesehatan. Hal ini terbukti karena kebanyakan rumah sakit telah menggunakan SIRS dalam membantu melakukan pemeriksaan kesehatan, diagnosis penyakit, perawatan dan sampai pada tahap pengambilan keputusan medis [1]. Tentunya dengan adanya SIRS pada sebuah rumah sakit kinerja pelayanan kesehatan kepada masyarakat akan semakin meningkat. Dampak dari sebuah Sistem Informasi berawal dari pengetahuan seseorang, pengalaman dan keterampilan menggunakan SIRS. Faktor inilah yang akan menentukan baik buruknya pelayanan kesehatan sebuah Rumah Sakit kepada masyarakat [2],[3].

Berdasarkan hasil survei yang diadakan di RSUD Dr Samratulangi Tondano Kabupaten Minahasa Sulawesi Utara, hasilnya menunjukan bahwa RSUD Dr Samratulangi Tondano menerapkan SIRS demi meningkatkan kinerja pelayanan kesehatan kepada masyarakat [4],[5]. Didalam pengoprasian SIRS pengguna banyak mengalami kendala berupa aplikasi error, data pasien yang tidak sesuai, jadwal dokter praktek yang tidak tepat, informasi pelayanan kesehatan yang tidak akurat dan sampai pada proses rawat inap pasien yang terkadang tidak sesuai data yang terdaftar[6]. 
Dengan berbagai kendala yang ada maka proses pengambilan keputusan dalam sebuah RS menjadi terhambat. Ketika hal ini terjadi pengguna SIRS lebih memilih alternative lain yaitu menggunakan cara menual berupa menuliskan data pasien pada kertas atau buku yang telah disediakan. Tentunya dengan berbagai kendala yang ada maka proses pelayanan kesehatan kepada masyarakat menjadi terhambat.

Berdasarkan beberapa masalah yang ada, peneliti tertarik untuk mengambil kasus ini untuk di jadikan bahan penelitian dengan tujuan untuk mengidentifikasi dampak penggunaan system informasi rumah sakit (SIRS) terhadap pelayanan kesehatan. Peranan seorang IT dan komponen teknologi informasi pada sebuah rumah sakit akan sangat bermanfaat dalam proses pemberian pelayanan kesehatan kepada masyarakat. Tentu dengan adanya peran seorang IT pada sebuah RS maka berbagai kendala dalam penggunaan SIRS dapat di reduksi[7],[8] dan tentunya hal ini dapat meningkatkan kualitas SIRS kedepan nanti [9],[10].

Penelitian ini bertujuan untuk mengidentifikasi dampak penggunaan system informasi rumah sakit (SIRS) terhadap pelayanan kesehatan di RSUD Dr Samratulangi Tondano Kabupaten Minahasa Sulawesi Utara [11]. Peneliti mengadopsi sebuah metode yaitu Human Organization Technology Fit Model (HOT-Fit) selain metode DeLone\&McLean's IS Succes Model untuk menguji dampak penggunaan sistem berdasarkan System Quality, Information Quality, Service Quality.

Berdasarkan beberapa literature yang yang telah peneliti baca, peneliti mengadopsi metode HOT-FIT untuk digunakan dalam penelitian ini. Alasan peneliti menggunakan metode HOT-FIT dikarenakan metode ini memiliki beberapa komponen penting yang dapat digunakan untuk menguji penggunaan system. Komponen tersebut adalah "Teknologi", Manusia" dan "Organisasi". Ketiga komponen ini memiliki masing-masing variable yaitu; System Quality, Information Quality, Service Quality, System Use, User Satisfation, Structure, Environment and Net Benefit [12],[13].

\section{METODE PENELITIAN}

\subsection{Sistem Informasi Rumah Sakit}

UUD No.46 pasal 1 Tahun 2014, Sistem Informasi Kesehatan (SIK) merupakan suatu kerangka yang terdiri dari data, informasi, indikator, prosedur, alat, teknologi dan sumber daya manusia. Semuanya itu saling berhubungan satu sama lainnya demi meningkat pelayanan kesehatan [14]. Departemen Kesehatan RI sudah menerapkan kebijakan dalam penyelenggaraan infrastruktur kesehatan demi meningkatkan kualitas pelayanan kesehatan di seluruh rumah sakit. MENKES/1171/PER/VI/2011 pasal 1 Ayat 1 menerangkan bahwa "Masing-masing rumah sakit wajib menerapkan Sistem Informasi Rumah Sakit”.

\subsection{DeLone\&McLean Is Succes Model}

Sistem Informasi (SI) berperan aktiv dalam menunjang kesuksesan sebuah organisasi [15][16]. Kesuksesan sebuah SI dapat dilihat dari berbagai riset atau penelitian yang pernah dilakukan [17][18][43]. DeLone\&McLean's IS Succes Model 2003 adalah model update terbaru yang lengkap dan memiliki jangkauan dan dampak dari kesuksesan sebuah sistem informasi[19],[20]. Model ini dapat dilihat pada gambar 1.

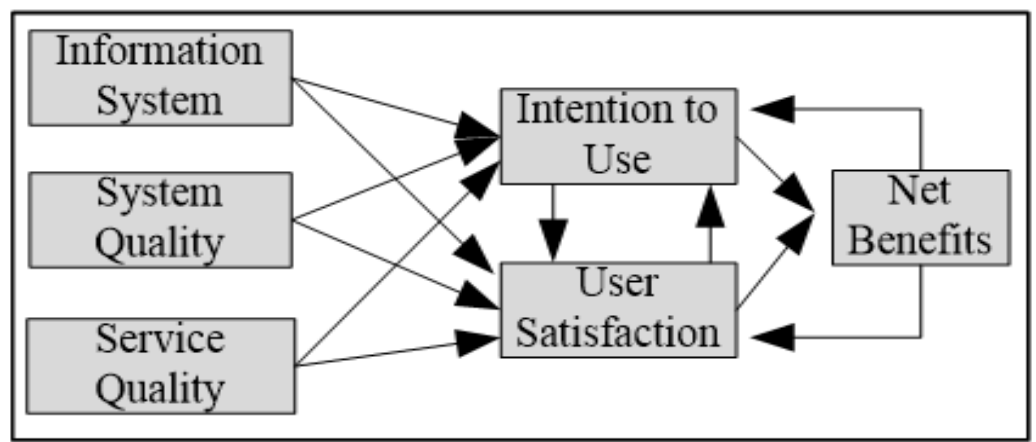

Gambar 1. DeLone dan McLean Model 2003.

\subsection{Human Organization Technology Fit Model (HOT-Fit).}

Yusof et al. 2006 menyatakan bahwa metode Hot-Fit merupakan sebuah metode lain yang dapat digunakan untuk mengidentifikasi dampak penggunaan sebuah sistem informasi rumah sakit terhadap pelayanan kesehatan. Metode ini menyediakan beberapa komponen penting dalam sebuah sistem informasi yaitu komponen Manusia (Human), Organisasi (Organization) dan Teknologi (Technology). Semua komponen ini nantinya akan memiliki hubungan satu sama lainnya, dapat dilihat pada gambar 2 


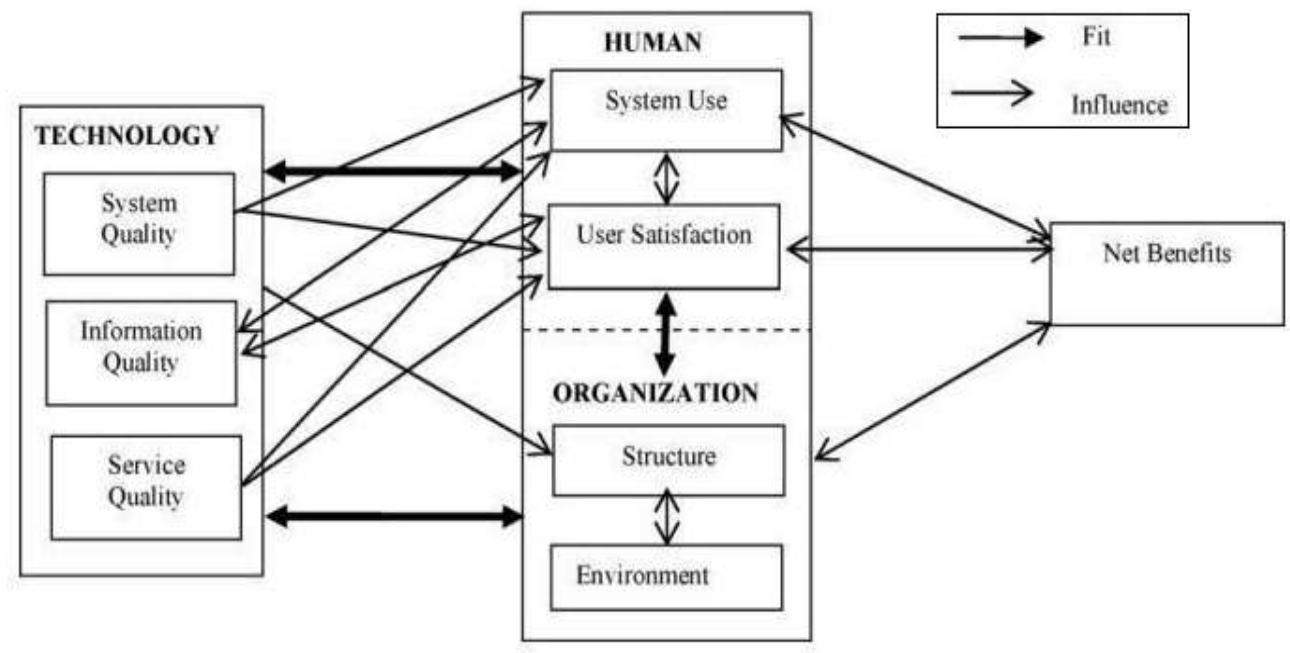

Gambar 2. Komponen Hot-Fit Model 2006

\subsection{Subyek Penelitian}

Yang menjadi objek penelitian dalam penelitian ini adalah semua pengguna Sistem Informasi Rumah Sakit (SIRS). Proses pengambilan data dilakukan dengan interview secara langsung kepada kepala RSUD Dr. Samratulangi Tondano Kabupaten Minahasa Sulawesi Utara dan semua pengguna SIRS. Selanjutnya dilakukan peyebaran kuesioner kepada para responden yaitu semua pengguna SIRS. Aktivitas sampling ini diadakan pada bulan september 2019. Kuesioner yang di pakai menggunakan format skala likert, kuesioner didistrubusiakan oleh peneliti secara lansung. Total dari penyebaran kuesioner sebanyak 150 rangkap dan menghasilkan tingkat tanggapan $100 \%$.

Tools yang digunakan untuk analisis data dalam penelitian ini adalah software SPSS 19 dan AMOS 18.0 yang dijalankan pada Windows 10. Pengolahan data menggunakan stastik deskriptif sebagai hasil analisis yang didukung untuk menggambarkan SIRS.

Penelitian yang dilakukan tidak terlepas dari penelitian terdahulu sebagai bahan perbandingan dan kajian, dapat dilihat pada tabel 1. Dan hasil penelitian dijadikan seabagai referensi dasar dari dari topik yang dibahas.

Tabel 1. Penelitian terdahulu dan tujun penelitian

\begin{tabular}{|c|c|}
\hline Research & Judul \\
\hline $\begin{array}{l}\text { Erlirianto, L. M., Ali, A. H. N., \& } \\
\text { Herdiyanti, A. (2015) }\end{array}$ & $\begin{array}{l}\text { The Implementation of the Human, Organization, and Technology-Fit } \\
\text { (HOT-Fit) Framework to Evaluate the Electronic Medical Record (EMR) } \\
\text { System in a Hospital. }\end{array}$ \\
\hline $\begin{array}{l}\text { ibuea, G. H., Napitupulu, T. A., \& } \\
\text { Condrobimo, A. R. (2017) }\end{array}$ & $\begin{array}{l}\text { An evaluation of information system using HOT-FIT model: A case study } \\
\text { of a hospital information system }\end{array}$ \\
\hline $\begin{array}{l}\text { Sallehudin, H., Satar, N. S. M., } \\
\text { Bakar, N. A. A., Baker, R., Yahya, } \\
\text { F., \& Fadzil, A. F. M. (2019) }\end{array}$ & $\begin{array}{l}\text { Modelling the Enterprise Architecture Implementation in the Public Sector } \\
\text { using HOT-Fit Framework }\end{array}$ \\
\hline Deharja, A., \& Santi, M. W. (2018) & $\begin{array}{l}\text { nformation system management based on hot- } \\
\text { adi bondowoso } 2018\end{array}$ \\
\hline $\begin{array}{l}\text { Fanny, N., Adi, K., \& Jati, S. P. } \\
\text { (2018) }\end{array}$ & $\begin{array}{l}\text { Keselamatan dan Kesehatan Kerja di RSUD Dr. } \\
\text { Model Hot fit }\end{array}$ \\
\hline $\begin{array}{l}\text { Dolev, E., Bitterman, Y., \& } \\
\text { Meirowitz, A. (2019) }\end{array}$ & $\begin{array}{l}\text { Comparison of marginal fit between CAD-CAM and hot-press lithium } \\
\text { disilicate crowns. }\end{array}$ \\
\hline $\begin{array}{l}\text { Ayuardini, M., \& Ridwan, A. } \\
\text { (2019) }\end{array}$ & $\begin{array}{l}\text { Implementasi Metode HOT FIT pada Evaluasi Tingkat Kesuksesan Sistem } \\
\text { Pengisian KRS Terkomputerisasi. }\end{array}$ \\
\hline Sukma, C., \& Budi, I. (2017) & $\begin{array}{l}\text { Penerapan Metode Hot Fit Dalam Evaluasi Sistem Informasi Manajemen } \\
\text { Rumah Sakit Di RSUD Jombang }\end{array}$ \\
\hline $\begin{array}{l}\text { Mirabolghasemi, M., Choshaly, S. } \\
\text { H., \& Iahad, N. A. (2019) }\end{array}$ & $\begin{array}{l}\text { Using the HOT-fit model to predict the determinants of E-learning } \\
\text { readiness in higher education: a developing Country's perspective }\end{array}$ \\
\hline
\end{tabular}

Dari beberapa contoh penelitian terdahulu, peneliti melihat bahwa semua penelitian yang dilakukan mengacu pada dampak penggunaan sebuah Sistem Informasi (SI). Dengan demikian pembahasan penelitian ini berfokus pada identifikasi dampak penggunaan sistem terhadap keberhasilan SIRS di RSUD Dr. Samratulangi Tondano Kabupaten Minahasa Sulawesi Utara, menggunakan Human-Organization-Technology Fit Model 2006. 
Available Online at https://ejurnal.stmik-budidarma.ac.id/index.php/mib DOI10.30865/mib.v4i1.1973

\subsection{Kerangka Penelitian}

Langkah-langkah penelitian dalam kasus ini yaitu latar belakang kasus atau masalah yang dihadapi di dalam RSUD Dr Samratulangi Tondano. Untuk kasus ini alur penelitian dimulai dari observasi, interview, penyebaran kuesioner, pengumpulan data, studi pustaka, dan sampai pada proses pengambilan kesimpulan, lebih lengkapnya dapat dilihat pada gambar 3 .

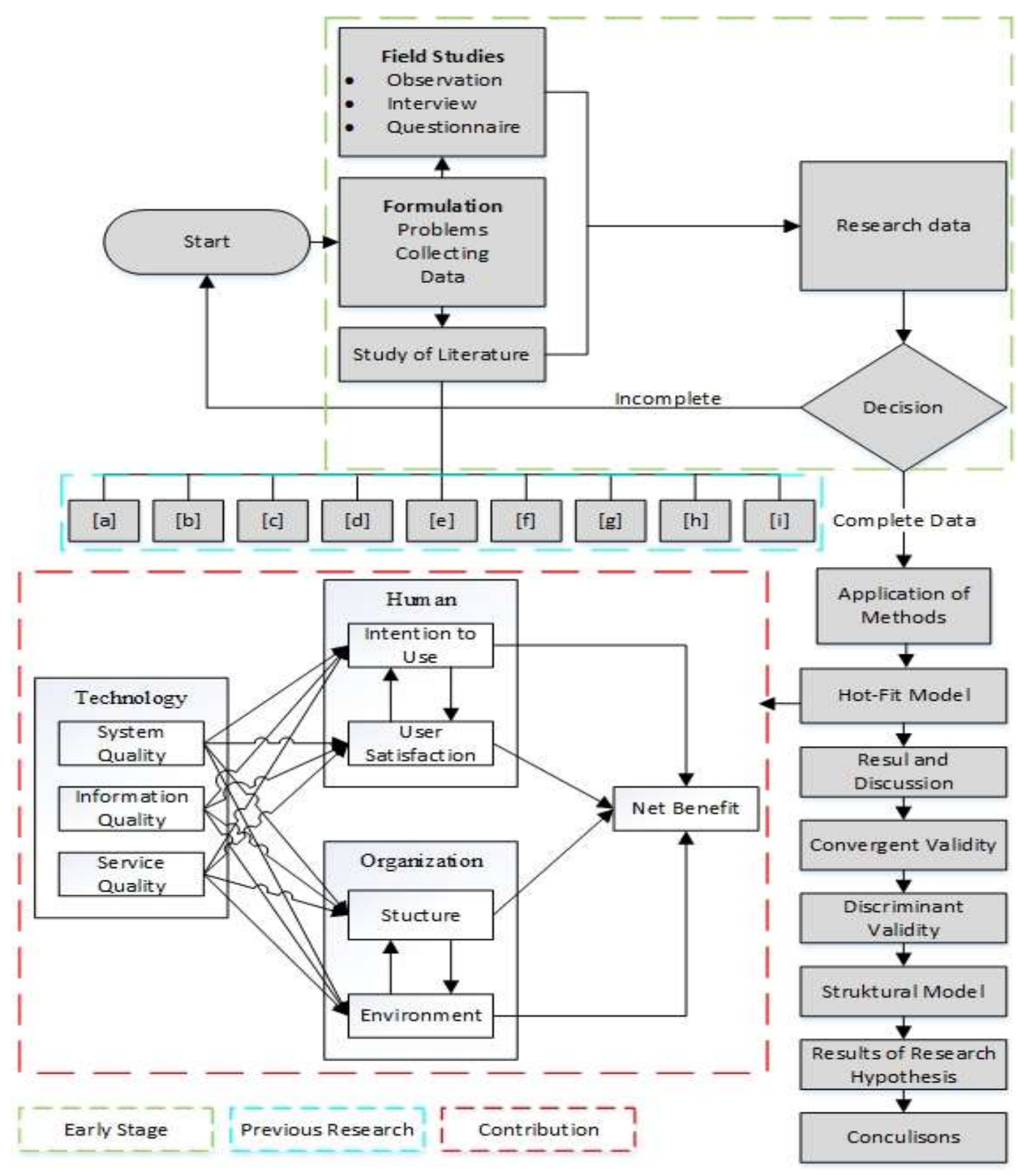

Gambar 3. Desain Alur Penelitian

\section{HASIL DAN PEMBAHASAN}

\subsection{Alat Penelitian}

Prosedur yang dilakukan peneliti di dalam kasus ini terdiri dari studi lapangan atau survei yang bertujuan untuk menggumpulkan semua informasi yang berkaitan dengan Sistem Informasi Rumah Sakit (SIRS), menganalisis permasalah SIRS dan studi literature yang relevan dengan SIRS. Peneliti menggunakan kuesioner dalam proses pengambilan data, kuesioner menggunakan format skala likert yang terdiri dari lima poin, yaitu; "Sangat Tidak Setuju”, “Tidak Setuju”, "Kurang Setuju”, "Setuju”, "Sangat Setuju”.

Kuesioner berjumlah lima halaman, pertanyaan yang dilampirkan berdasarkan delampan indicator yang terdapat pada HOT-Fit Model 2006 yaitu terdiri dari indikator "Kualitas Sistem" isinya lima pertanyaan, indicator "Kualitas Informasi" isinya lima pertanyaan, indicator "Kualitas Pelayanan" isinya tiga pertanyaan, indicator "Penggunaan Sistem" isinya lima pertannyaan dan indicator "Manfaat Bersih" yang isinya enam pertanyaan. 


\subsection{Struktur Penelitian.}

Sesuai dengan tujuan penelitian maka dapat di gambarkan struktur seperti gambar 4. Untuk menguji dampak penggunaan SIRS terhadap pelayanan kesehatan di RSUD Dr. Samratulangi Tondano Kabupaten Minahasa Sulawesi Utara maka di perlukan lima indikator utama, yaitu; Kualitas Sistem, Kualitas Informasi, Kualitas Layanan, Penggunaan dan Net Benefit, empat indikator ini dapat dilihat pada Gambar 4. Struktur dan hipotesis penelitian.

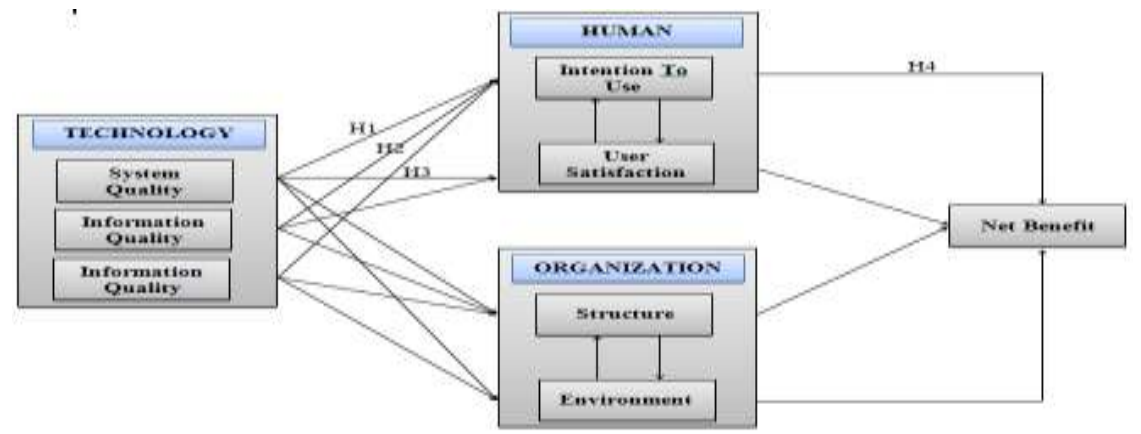

Gambar 4. Struktur dan Hipotesis Penelitian Hot-Fit Model

\subsection{Hipotesis Penelitian}

Berdasarkan hipotesis HOT-Fit Model, ada empat indikator keberhasilan Sistem Informasi (SI). Keempat indikator memiliki dampak pada penggunaan system informasi rumah sakit (SIRS) terhadap pelayanan kesehatan di RSUD Dr Samratulangi Tondano Kabupaten Minahasa Sulawesi Utara. Di dalam penelitian di temukan bahwa kualitas sistem, kualitas informasi, kualitas layanan, penggunaan dan net benefit adalah faktor yang berpengaruh dalam menentukan pelayanan kesehatan kepada masyarakat. Dengan demikian, penelitian ini akan mengusulkan beberapa permasalahan yang terkait dengan dampak penggunaan system informasi rumah sakit (SIRS) terhadap pelayanan kesehatan di RSUD Dr. Samratulangi Tondano Kabupaten Minahasa Sulawesi Utara.

\subsection{Analisis Data}

Tools yang digunakan dalam penelitian ini adalah software SPSS 19 dan AMOS 18.0 untuk menampilkan diagram alur serta hasil analisa yang dapat dilihat pada gambar 5, tools ini dijalankan pada Windows 10 untuk kebutuhan analisis data. Pengolahan data menggunakan stastik deskriptif sebagai hasil analisis yang didukung untuk menggambarkan SIRS. Hasil analisis data yang di peroleh digunakan untuk melihat hubungan yang berkaitan dengan empat indicator yang tersedia (Kualitas Sistem, Kualitas Informasi, Kualitas Layanan, Penggunaan dan Net Benefit).

Pendistribusian informasi berupa kuesioner di analisis berdasarkan sampel yang ada. Dari 150 responden yang terdiri dari 93 perempuan dan 57 laki-laki, maka dapat di simpulkan bahwa sampel yang di ambil adalah jumlah pengguna SIRS di RSUD Dr. Samratulangi Tondano Kabupaten Minahasa Sulawesi Utara. Berdasarkan jumlah responden yang di ambil peneliti dapat menyimpulkan bahwa terjadi perbedaan jenis kelamin dan latar belakang pendidikan dari total responden yang di ambil secara random. Perbedaan ini menunjukan pengguna SIRS di RSUD Dr. Samratulangi Tondano Kabupaten Minahasa Sulawesi Utara lebih dominan perempuan di bandingkan laki-laki dengan latar belakang pendidikan mulai dari D3 sampai dengan S2.

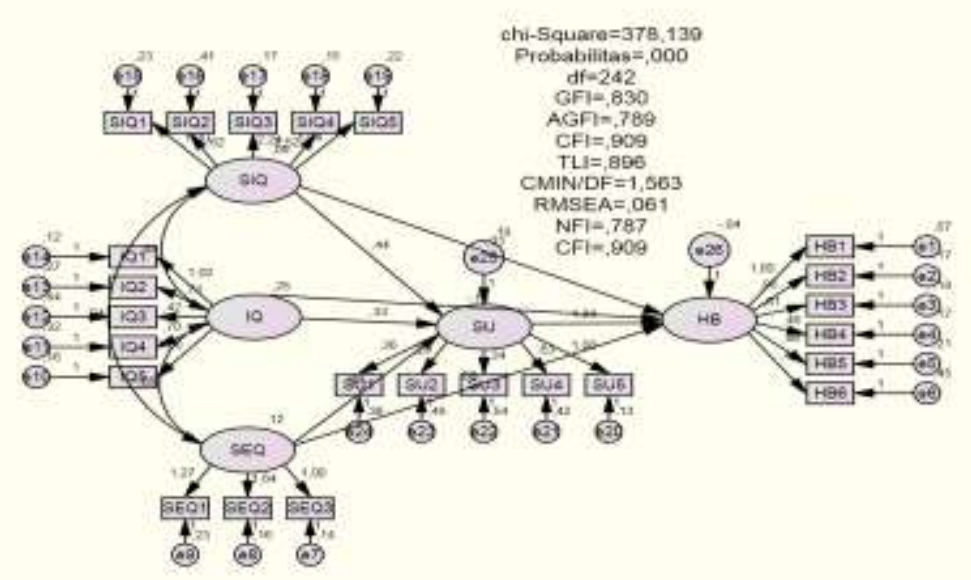

Gambar 5. Output Diagram Uji Statistik Pengguna Sistem 
JURNAL MEDIA INFORMATIKA BUDIDARMA

Volume 1, Nomor 1, Januari 2020, Page 216-224

ISSN 2614-5278 (media cetak), ISSN 2548-8368 (media online)

Available Online at https://ejurnal.stmik-budidarma.ac.id/index.php/mib DOI10.30865/mib.v4i1.1973

\subsection{Uji Validitas Konvergen}

Validats konvergen merupakan tingkat korelasi antara instrument penguukuran yang berbeda yang digunakan untuk menguukur konstruk yang sama. Untuk kasus ini dapat dilakukan dengan Confirmatory factor analysis (CFA), tujuannya untuk menguji validitas convergen apakah setiap item terbukti secara efektif dan bisa memberikan jawaban yang valid. Daftar standarised estimate, dengan rata-rata varians diekstrak (AVE), komposit kehandalan (CR). Seperti yang ditunjukkan dalam tabel 2, kebanyakan setiap item standarised estimate lebih besar dari 0.7. Dengan demikian, skala bisa mendukung dengan baik pada validitas konvergen [30][31].

Tabel 2. Reliability and AVE Construc cted by Observable Variable and Latent Variable

\begin{tabular}{llcll}
\hline Lat.variable & Obs. & Standarized & \multirow{2}{*}{ CR } & \multirow{2}{*}{ AVE } \\
& Variable & Estimate & & \\
\hline Service & SEQ1 & 0,875 & & \\
Quality & SEQ2 & 0,816 & 0,920 & 0,794 \\
& SEQ3 & 0,976 & & \\
& IQ1 & 0,826 & & \\
Information & IQ2 & 0,968 & & \\
Quality & IQ3 & 0,899 & 0,935 & 0,744 \\
& IQ4 & 0,819 & & \\
& IQ5 & 0,781 & & \\
& SIQ1 & 0,939 & & \\
System & SIQ2 & 0,986 & & \\
Quality & SIQ3 & 0,857 & 0,959 & 0,826 \\
& SIQ4 & 0,895 & & \\
& SIQ5 & 0,861 & & \\
& SU1 & 0,942 & & \\
& SU2 & 0,949 & & \\
System Use & SU3 & 0,873 & 0,963 & 0,839 \\
& SU4 & 0,951 & & \\
& SU5 & 0,861 & & \\
& HB1 & 0,871 & & \\
& HB2 & 0,855 & & \\
Net Benefit & HB3 & 0,81 & 0,959 & 0,824 \\
& HB4 & 0,928 & & \\
& HB5 & 0,791 & & \\
\hline & HB6 & 0,819 & & \\
\hline
\end{tabular}

\subsection{Uji Validitas Diskriminan}

Validitas deiskriminan yaitu sebuah ukuran untuk menyatakan seberapa besar hasil yang di dapat berdasarkan standar yang yang sudah di tentukan. Pengujian ini dilakukan untuk mengukur apakah dari dua faktor statistik yang berbeda menghasilkan data yang valid [32] dengan membandingkan square root of AVE dan faktor korelasi koefisien [33][34]. Masing-masing indicator memiliki nilai tersendiri seperti nilai Net Benefit, System Quality (S.Q), Information Quality (I.Q), System Quality (S.Q), System Use (S.U), yang dapat dilihat pada tabel 3.

Tabel 3. The Square Root of AVE and Factor Correlation Coefficients

\begin{tabular}{llllll}
\hline & $\begin{array}{l}\text { Net } \\
\text { Benefit }\end{array}$ & S.Q & I.Q & S.Q & S.U \\
\hline HB & 0,085 & & & & \\
SIQ & $0,8,19$ & 0,909 & & & \\
IQ & 0,765 & 0,820 & 0,862 & & \\
SEQ & 0,769 & 0,563 & 0,788 & 0,891 & \\
SU & 0,823 & 0,678 & 0,806 & 0,776 & 0,915 \\
\hline
\end{tabular}

\subsection{Structural Model Analysis}

Setelah asumsi SEM dilakukan maka pengujian analisis dilakukan menggunakan enam indeks untuk mengukur keseluruhan model yang cocok untuk kuantifikasi hasil kesalahan dari pendekatan (RMSEA)[35][36], indek fit (GFI), disesuaikan dengan tiga indeks fit (AGFI), perbandingan indeks (CFI), komparatif dan kesesuaian dari indeks yang diharapkan (PCFI)[37][38]. 
Tabel 4. Analysis of Research Model Tntention To Use

\begin{tabular}{llll}
\hline $\begin{array}{l}\text { Goodness of } \\
\text { fit index }\end{array}$ & $\begin{array}{l}\text { Cut-off } \\
\text { value }\end{array}$ & $\begin{array}{l}\text { Model } \\
\text { Research }\end{array}$ & Model \\
\hline $\begin{array}{l}\text { Significant } \\
\text { probability }\end{array}$ & $\geq 0.05$ & 0,140 & Good Fit \\
RMSEA & $\leq 0.08$ & 0,026 & Good Fit \\
GFI & $\geq 0.90$ & 0,878 & $\begin{array}{l}\text { Marginal } \\
\text { Fit }\end{array}$ \\
AGFI & $\geq 0.80$ & 0,844 & Good Fit \\
CMIN/DF & $\leq 2.0$ & 1,100 & Good Fit \\
TLI & $\geq 0.90$ & 0,982 & Good Fit \\
CFI & $\geq 0.90$ & 0,984 & Good Fit \\
\hline
\end{tabular}

\subsection{Test Results of Research Hypothesis}

Berdasarkan hasil pengujian dari keempat hipotesis, hasilnya menunjukan bahwa keempat hipotesis yang di ajukan meberikan efek positive atau diterima[39]. Hipotesis yang di terima adalah kualitas sistem terhadap pengguna sistem (H1) dengan nilai siknifikan 0.046 dan Limit 0.05 , sehingga (H1) menyatakan bahwa kualitas sistem berdampak pada pengguna system[40]. Kualitas informasi terhadap pengguna sistem (H2) memiliki nilai siknifikan 0.024 dan Limit 0.05 , sehingga nilai (H2) menyatakan bahwa kualitas informasi berdampak pada pengguna system[41]. Kualitas pelayanan terhadap pengguna sistem (H3) memiliki nilai siknifikan 0.000 dan Limit 0.05, sehingga nilai (H3) menyatakan bahwa kualitas pelayanan berdampak pada pengguna system[42]. Ketiga indicator yaitu kualitas system, kualitas informasi dan kualitas pelayanan memiliki manfaat bersih dengan nilai siknifikan 0.000 dan Limit 0.05 , sehingga menunjukkan bahwa ketiga indicator tersebut memiliki manfaat bersih, dapat dihat pada tabel 5 .

Tabel 5. Hasil Hipotesis

\begin{tabular}{lllll}
\hline$*$ & Hipotesis & P & Limit & Remarks \\
\hline $\mathbf{H 1}$ & $\begin{array}{l}\text { System Quality (+) } \\
\text { Intention to Use }\end{array}$ & 0,046 & 0,05 & Influence (+) \\
$\mathbf{H 2}$ & $\begin{array}{l}\text { Information Quality (+) } \\
\text { Intention to Use Use } \\
\text { H3 }\end{array}$ & 0,024 & 0,05 & Influence (+) \\
Intention to Use Use & 0,000 & 0,05 & Influence (+) \\
$\mathbf{H 4}$ & $\begin{array}{l}\text { Intention to Use (+) } \\
\text { Net Benefits }\end{array}$ & 0,000 & 0,05 & Influence (+) \\
\hline
\end{tabular}

\section{KESIMPULAN}

Penenelitian ini hanya sebatas mengidentifikasi dampak penggunaan system informasi rumah sakit (SIRS) terhadap pelayanan kesehatan. Dengan dilakukannya penelitian ini maka peneliti dapat memberikan saran kepada pihak RSUD Dr Samratulangi Tondano mengenai penggunaan SIRS ke depan nanti. Objek penelitian dan responden yang di ambil peneliti adalah seluruh pengguna SIRS di RSUD Dr Samratulangi Tondano Kabupaten Minahasa Sulawesi Utara.

Berdasarkan hasil pengujian dan analisa yang peneliti lakukan, dapatr di simpulkan bahwa dari keempat hipotesis yang diajukan sebanyak empat hipotesis diterima, yaitu sebagai berikut :

a. Komponen teknologi yang terdiri dari kualitas sistem, kualitas informasi dan kualitas layanan berdampak pada penggunaan system.

b. Pada umumnya pengguna SIRS lebih banyak menggunakan fungsi registrasi dan administrasi dari pada fungsi klinis lainnya. Faktor utama yang sangat berperan penting dalam menunjang pelayanan kesehatan adalah faktor ketersediaan Teknologi Informasi (TI) dan keterlibatan orang Teknik Informatika (TIK) dalam pennggunaan SIRS

Faktor ketersediaan unit Teknologi Informasi (IT) dan ahli Teknik Informatika (TIK) akan berdampak pada tingkat pelayanan kesehatan kepada masyarakat. Penelitian dapat memberikan pemahaman mengenai pentingnya sebuah Teknologi Informasi (TI) dan keterlibatan orang Teknik Informatika (TIK) dalam penggunaan SIRS demi meningkatkan proses pelayanan kesehatan kepada masyarakat.

\section{REFERENCES}

[1]. E. \&. B. G. Shortliffe, "Data biomedis: akuisisi mereka, penyimpanan, dan penggunaan," Dalam informatika Biomedis, no. Springer London, pp. 39-66, 2014. 
[2] M. Khalifa, "Hambatan untuk sistem informasi kesehatan dan implementasi catatan medis elektronik," Sebuah studi lapangan rumah sakit Arab Saudi, vol. 21, no. Procedia Ilmu Komputer, pp. 335-342, 2013.

[3] M. Khalifa, "Teknis dan Manusia Tantangan Sistem Informasi Rumah Sakit Pelaksana di Arab Saudi," Jurnal Kesehatan Informatika di Negara Berkembang, 2014

[4] T. CANADA, "Enterprise Architecture Transformation Process from a Federal Government Perspective," Prescott Valley, no. Northcentral University., 2016.

[5] El-Kareh R, Hasan HAI, Schiff GD. Menggunakan dari Informasi kesehatan teknologi untuk mengurangi diagnostik kesalahan. BMJ qual Saf 2013; 22: ii40-51, http://dx.doi.org/10.1136/bmjqs-2013-001884.

[6] chen ET. Meneliti itu mempengaruhi dari informasi teknologi di modern kesehatan peduli. Di: Eff. metode Mod. Healthc. Serv. Qual. Eval. Lowell, KAMI: IGI Global; 2016, http://dx.doi.org/10.4018/978-1-4666-9961-8.ch006. p.

[7] P. A. Dabholkar, "How to Improve Perceived Service Quality by Increasing Customer Participation," in Proceedings of the 1990 Academy of Marketing Science (AMS) Annual Conference, B. J. Dunlap, Ed. Cham: Springer International Publishing, 2015, pp. 483-487.

[8] Y. K. Dwivedi et al., "Research on information systems failures and successes: Status update and future directions," Inf. Syst. Front., vol. 17, no. 1, pp. 143-157, 2015.

[9] Buntin, MB, Burke, MF, Hoaglin, MC, \& Blumenthal, D. (2011). Manfaat teknologi informasi kesehatan: review literatur terbaru menunjukkan hasil didominasi positif. Urusan kesehatan, 30 (3), 464-471.

[10] K. Yousapronpaiboon, "SERVQUAL: Measuring Higher Education Service Quality in Thailand," Procedia - Soc. Behav. Sci., vol. 116, pp. 1088-1095, 2014.

[11] T. D. Nguyen, T. M. Nguyen, and T. H. Cao, "Information Systems Success: A Literature Review," in Future Data and Security Engineering: Second International Conference, FDSE 2015, Ho Chi Minh City, Vietnam, November 23-25, 2015, Proceedings, T. K. Dang,

[12] R. Wagner, J. Küng, N. Thoai, M. Takizawa, and E. Neuhold, Eds. Cham: Springer International Publishing, 2015, pp. 242-256.

[13] Pemerintah Republik Indonesia, Peraturan Pemerintah Republik Indonesia Nomor 46 Tahun2014.,2014. [online]. http://www.depkes.go.id/resources/download/general/PP\%20Nomor\%2046\%20Tahun\%202014.pdf

[14] Maryati Mohd. Yusof, Jasna, Kuljis, Anastasia Papazafeiropoulou, Lampors K. Stergioulas, "Sebuah Kerangka Evaluasi Sistem Informasi Kesehatan: Manusia, Organisasi dan Teknologi-Fit Faktor International Journal of Medical(HOTFit),"Informatics,pp 377-385, 2008.

[15] Rumambi, F. R., Santoso, A. J., \& Setyohadi, D. B. (2017, September). Identification of Factors Influencing the Success of Hospital Information System (SIRS) by Hot-Fit Model 2006: A Case Study of RSUD Dr Samratulangi Tondano, Minahasa Regency, North Sulawesi. In 2017 International Conference on Soft Computing, Intelligent System and Information Technology (ICSIIT) (pp. 202-207). IEEE.

[16] Sasono, D. S., Rumambi, F. R., Priskila, R., \& Setyohadi, D. B. (2017, October). Integration of pharmacy and drug manufacturers in RSUD Dr Samratulangi Tondano by ESB WSO2 to improve service quality:(A case study of RSUD Dr Samratulangi Tondano, Minahasa Regency, North Sulawesi). In 2017 4th International Conference on Information Technology, Computer, and Electrical Engineering (ICITACEE) (pp. 249-254). IEEE.

[17] Rumambi, F. R., Amalia, C., \& Alexander, R. Identifikasi Penerapan ERP dan Resiko Managemen Pada RSUD Dr Samratulangi Tondano Kabupaten Minahasa-Sulawesi Utara (In press). JSINBIS (Jurnal Sistem Informasi Bisnis), 8(2).

[18] Y. K. Dwivedi et al., "Research on information systems failures and successes: Status update and future directions," Inf. Syst. Front., vol. 17, no. 1, pp. 143-157, 2015.

[19] S. Petter, W. DeLone, and E. R. McLean, "Information Systems Success: The Quest for the Independent Variables," J. Manag. Inf. Syst., vol. 29, no. 4, pp. 7-62, 2013.

[20] W. H. DeLone and E. R. McLean, "Information Systems Success Measurement," Found. Trends ${ }^{\circledR}$ Inf. Syst., vol. 2, no. 1, pp. 1-116, 2016.

[21] Erlirianto, L. M., Ali, A. H. N., \& Herdiyanti, A. (2015). The Implementation of the Human, Organization, and Technology-Fit (HOT-Fit) Framework to Evaluate the Electronic Medical Record (EMR) System in a Hospital. Procedia Computer Science, 72, 580-587.

[22] Sibuea, G. H., Napitupulu, T. A., \& Condrobimo, A. R. (2017, November). An evaluation of information system using HOT-FIT model: A case study of a hospital information system. In 2017 International Conference on Information Management and Technology (ICIMTech) (pp. 106-111). IEEE.

[23] Sallehudin, H., Satar, N. S. M., Bakar, N. A. A., Baker, R., Yahya, F., \& Fadzil, A. F. M. (2019). Modelling the Enterprise Architecture Implementation in the Public Sector using HOT-Fit Framework. International Journal of Advanced Computer Science and Applications, 10(8), 191-198.

[24] Deharja, A., \& Santi, M. W. (2018). The evaluation of hospital information system management based on hot-fit model at rsu dr. h. koesnadi bondowoso 2018. In Proceeding of the 1st International Conference on Food and Agriculture.

[25] Fanny, N., Adi, K., \& Jati, S. P. (2018). Evaluasi Sistem Informasi Keselamatan dan Kesehatan Kerja di RSUD Dr. Moewardi Menggunakan Model Hot Fit (Doctoral dissertation, UNIVERSITAS DIPONEGORO).

[26] Dolev, E., Bitterman, Y., \& Meirowitz, A. (2019). Comparison of marginal fit between CAD-CAM and hot-press lithium disilicate crowns. The Journal of prosthetic dentistry, 121(1), 124-128.

[27] Ayuardini, M., \& Ridwan, A. (2019). Implementasi Metode HOT FIT pada Evaluasi Tingkat Kesuksesan Sistem Pengisian KRS Terkomputerisasi. Faktor Exacta, 12(2), 122-131.

[28] Sukma, C., \& Budi, I. (2017). Penerapan Metode Hot Fit Dalam Evaluasi Sistem Informasi Manajemen Rumah Sakit Di RSUD Jombang. Jurnal Informasi dan Komputer, 5(1), 34-41.

[29] Mirabolghasemi, M., Choshaly, S. H., \& Iahad, N. A. (2019). Using the HOT-fit model to predict the determinants of Elearning readiness in higher education: a developing Country's perspective. Education and Information Technologies, 1 22.

[30] W. H. DeLone and E. R. Mclean, "The DeLone and McLean Model of Information Systems Success: A Ten-Year Update,” J. Manag. Inf. Syst. / Spring, vol. 19, no. 4, pp. 9-30, 2003. 
JURNAL MEDIA INFORMATIKA BUDIDARMA

Volume 1, Nomor 1, Januari 2020, Page 216-224

ISSN 2614-5278 (media cetak), ISSN 2548-8368 (media online)

Available Online at https://ejurnal.stmik-budidarma.ac.id/index.php/mib

DOI10.30865/mib.v4i1.1973

[31] A. I. Ojo, "Validation of the DeLone and McLean Information Systems Success Model," Healthcare Informatics Research, vol. 23, no. 1. pp. 60-66, Jan-2017.

[32] T. Zhou and H. Li, "Computers in Human Behavior Understanding mobile SNS continuance usage in China from the perspectives of social influence and privacy concern," Comput. Human Behav., vol. 37, pp. 283-289, 2014.

[33] J. Henseler, C. M. Ringle, and M. Sarstedt, "A new criterion for assessing discriminant validity in variance-based structural equation modeling,” J. Acad. Mark. Sci., vol. 43, no. 1, pp. 115-135, 2015.

[34] M. B. a. H. Alam.G.R, "Critical Factors Influencing Decision to Adopt Human Resource Information System (HRIS) in Hospitals, "Computer Science and Engineering, no. DOI:10.1371/journal.pone.0160366, 2016.

[35] Cahyaningrum.N, "Evaluasi Penerapan Sistem Komputerisasi Pendaftaran Pasien di Balai Besar Kesehatan Paru Masyarakat (BBKPM) Surakarta," Jurnal Ilmiah Rekam Medis dan Informatika Kesehatan, Vols. INFOKES, VOL 6 NO 2, no. ISSN:2086 - 2628, 2016.

[36] Saputra.A.B, "The Identification of Success Factors Implementation Management Information of Hospital," Jurnal Penelitian Pers dan Komunikasi Pembangunan, vol. Vol. 19 No.3, no. ISSN 2527-693X, pp. 135-148, 2016.

[37] S. A. P. Murnita.R, "Evaluation of the Performance of Pharmacy Management Information System At Roemani Muhammadiyah Hospital," Jurnal Manajemen Kesehatan Indonesia, vol. Volume 4. No 1, no. DOI: https://doi.org/10.14710/jmki4111-1912691, 2016.

[38] W. A. N. Pamugar.H, "Model Evaluasi Kesuksesan dan Penerimaan Sistem Informasi E-Learning pada Lembaga Diklat Pemerintah," Scientific Journal of Informatics, Vols. Vol. 1, No. 1, no. ISSN 2407-7658, 2014.

[39] S. A. A. M. Mahendra Sari.M.M, "Evaluasi Sistem Informasi Managemen Rumah Sakit (SIMRS)," in Seminar Nasional Sistem Informasi Indonesia, Yogyakarta, 1 November 2016.

[40] A. A. A. C. S. Alharbi.F, "Alharbi.F, Atkins.A, Stanier.C 2016 Understanding the determinants of Cloud Computing adoption in Saudi healthcare organisations," no. This article is published with open access at Springerlink.com DOI 10.1007/s40747-016-0021-9, pp. 155-171, 2016.

[41] S.A. P. Thenu.V.J, "Evaluation of Health Center Management Information System of Generic SIKDA,"Manajemen Kesehatan Indonesia, vol. Volume. 4 No. 2, 2016. 2015.

[42] S.A. P. Thenu.V.J, "Evaluation of Health Center Management Information System of Generic SIKDA,"Manajemen Kesehatan Indonesia, vol. Volume. 4 No. 2, 2016. 2015.

[43] S. Robo, D. B. Setyohadi and A. J. Santoso, "An identification of success of academic system application using Delone and McLean design (Case study at Wira Husada school of health science Yogyakarta)," 2018 International Conference on Information and Communications Technology (ICOIACT), Yogyakarta, 2018, pp. 827-832. doi:10.1109/ICOIACT.2018.8350756 